\title{
The role of commercial advertisements directed to children influencing on parents' purchasing decision
}

\author{
Sima Ghaleb Magatef ${ }^{\mathrm{a}^{*}}$ and Raed Ahmad Momani ${ }^{\mathrm{a}}$
}

\begin{tabular}{l}
${ }^{a}$ University of Petra, Jordan \\
\hline C H R O N I C L E \\
\hline Article history: \\
Received: July 92019 \\
Received in revised format: July \\
192019 \\
Accepted: August 21, 2019 \\
Available online: \\
August 21, 2019 \\
\hline Keywords: \\
Commercials Advertising (ads) \\
Ads Message content \\
Ads Frequency \\
Characters used in the ads \\
Means of ads, children awareness \\
Children interest \\
Children response \\
Parent's purchase decision \\
Direct response \\
Indirect response \\
Jordanian parents \\
\hline
\end{tabular}

\begin{abstract}
A B S T R A C T
A study was conducted on the role of commercial advertisement directed to children for influencing parents' purchasing decision. The study targeted parents, taking into account all demographic factors. The main objective of the study was to determine the extent of commercial ads influencing on parents' decision either directly without children's effect or with children effect. To achieve this, a random sample was selected from parents of children aged 2-14 years. 530 copies of the questionnaire were distributed, and 474 valid ones were retrieved, which represented for $89.43 \%$ of the sample size. After the collection of the questionnaires, the data were recorded and analyzed. The results show that there was an effect of independent variables (advertising campaigns) on the intermediary variable (children), as well as the effect on the dependent variable (parents' purchasing decision). The results also show that the entry of the intermediary variable (children) on the model had a direct and indirect effect, but its effect was relative rather than total. So, there is an effect of the independent variables (commercial ads) on the dependent variable (parents' purchasing decision) with or without the existence of intermediary. Based on the results of the study, the researchers recommended that organizations should design advertisements that target parents directly to convince them to make purchasing decision without their children mediation, and design other advertisements to target children because they can have influence over parents and can convince them to make purchasing decision. In addition, it is necessary for organizations to focus on the content of advertising messages, and to repeat them periodically, taking into account the renewal of content from time to time. They should also select effective ways to post their advertisements, especially on social media platforms in different times.
\end{abstract}

(C) 2020 by the authors; licensee Growing Science, Canada

\section{Introduction}

The last years of the twenty-first century witnessed a great development in communication technology, and the easy accessibility to the consumer through various means of advertising, including internet networks and social media sites, in addition to satellite channels which were spread at a large scale as a result of the rapid technological and scientific progress that swept all over the world, making the world a small village-like connected through one network via satellite. Without a doubt, children are exposed to these networks and the various ads presented on them, which creates the desire in them to get many products by influencing parents to make the decision to purchase them. Today, children are intellectually and mentally mature and capable of distinguishing between many advertised products, especially in light of the great sophistication of communication technology and means of advertising. Nevertheless, misinterpretation of messages shown on these various means has an impact on parents' practices, requiring them to monitor their children's accounts, and be with them when they are under media exposure in order to intensify control over them and limit the influence over them (Tsfati et al., 2005). Parents must be aware of how children deal with advertisements and how ads influence their choice of goods (Spielvogel \& Terlutter, 2013), because parental dystrophy minimizes this effect. This requires an urgent need to search for determinants of various means of advertising, particularly television and social media on children, and the impact on children choices of commodities, as well as their wants especially during the growing stage (Beales III \& Kulick, 2013). Many studies have focused on the need to increase

* Corresponding author. Tel.: +96 2797414305

E-mail address: simaghaleb@hotmail.com (S. G. Magatef) 
parents' understanding for the impact of ads targeting children on their choices, especially TV ads which are strong sources of information (Ip et al., 2007), requiring intense attention to how ads are produced, and how they reach children. (Bakir, 2009). However, despite all restrictions, advertisements still have effects over children, which requires more control over them (Sener et al., 2010). Several studies have also shown the positive and negative effects of these advertisements posted on children's channels on children mental, physical, linguistic and psychological development (Alabdali, 2011). This requires cooperation between advertising agencies and educational institutions to prepare these ads along with linking between all types of ads and social values (Rajab, 2015), in addition to focusing on social marketing campaigns and evaluating them (Ng et al., 2014). Generally, ads have a clear impact on children's purchasing behavior as they can create awareness and attention towards the advertised products, which will become their favorite products especially when using characters in these ads who can make the child believe in the qualities of the product, affecting his/her purchasing wants, (Sara Vikas, 2013). In addition, advertisers seek to use persuasive marketing techniques when advertising children's products, whether through the Internet, social media sites, or even in channels dedicated for children and so on, where the focus of these ads is made in the afternoon time and weekends (Li et al., 2016). In addition to the current interest in advertising these ads on children's websites which are among the modern means of advertising that have become available to the public people from all ages. (Ustjanauskas et al., 2014).

Because of the attractiveness of advertising and its high impact on the public, particularly on children, who are not only the target of advertising, but also representing a market share in the short term and potential consumers in the long term. Especially in the light of globalization and its associated Western and Arab cultural trends spreading through advertising means on the Internet and social media which promote all necessary and unnecessary demands, both useful and harmful, particularly for children aged between two and fourteen. Advertising is seen as an indirect means of communication influenced by the world's revolution in communications and information. Commercial advertisements, especially those directed to children, are considered to be the most controversial topics by intellectuals, academicians, educators and even parents who have many objections towards them. Because the children cannot understand the true meaning of ads, which requires from us to do more research to reach the relationship that links between commercial ads and parents' purchasing decision, whether influenced by their children or not when exposed to ads the children might be a consumer influencing many purchasing decisions of parents, and also might be a future customer for many companies. That is why many producers and marketers direct their marketing efforts to children despite their limited information, but children curiosity and their desire to learn and imitate others greatly push them to accept all the information presented to them through advertisements that may lead them to incorrect choices; sometimes they might be unhealthy. As children are the future consumers of many goods and services, this calls upon marketers to establish affiliation and loyalty in children for many brands by designing advertising campaigns dedicated to children, that make them remember these brands and convince their parents to make purchasing decision. Parents might respond to their children in some cases and reject their requests in others. The question arises here is where the role of commercial ads influences the purchasing decision of parents lie or not. Can the content of an advertising message affect children in their attempts to persuade parents to make a purchasing decision? Is there a great echo for the repetition of the ad? More than one time on children's behavior and attitudes? Can the characters in the ads have influence on children's behavior so that they persuade parents to make the decision to buy their products? Were various means of advertising able to reach as many children as possible or, is television still the most effective on children behavior? Does the time of the ads play a role in influencing the decisions of children to choose the advertised products? Have commercial advertisements been able to create awareness and interest in children and make them respond to advertisements in order to make a purchasing decision?

Have social networks become the most influential at the moment? Can children affect parents to meet their needs? Finally, can commercials ads affect the purchasing decision of parents directly or indirectly through children? Henceforth, the importance of the study emerges, which stems from the vital role played by commercial ads in the great impact on children and the extent of its contribution to the crystallization of their tendencies, and their mental and physical abilities to change their behavior and attitudes of purchasing, and then influence the parents to get some products. This might lead us to make the relationship between commercial ads and the process of purchasing decision of parents subject to practical and applied study, to increase the effectiveness of commercials ads role as a source of information on the one hand and to be away from the thinking, fantasies and expectations of the designers of commercial ads which often based on self-non-objective experiences. The practical importance of this study lies in the vital role played by commercial advertisements as a source of knowledge regarding various products and brands, and helping marketing individuals to recognize their role as one of the influencers on purchasing decision and child's learning of consumer behavior, and helping him determine his needs and desires. The study will also focus on children and what they get right from the beginning of their life, which contributes to building their personalities and awareness. Moreover, the significance of the study also stems from the focus on the parents' role in controlling their children, and the various advertisements they follow to guide them in confronting the challenges of globalization.

The issue is also be looked at in terms of the importance of family purchasing decisions based on children participation. The importance of this study lies in the extent of the great impact of advertising on children and children pressure on parents. In addition to the importance of the results this study provides, which stem from realistic information that can guide specialists to the most important problems that children may face as a result of exposure to advertisements, which may lead them to inappropriate choices. This study also tackles a vital issue and an economic and social aspect, which represents one of the aspects of economic development represented in the rise of consumption rates of many products due to exposure to advertisements. This leads us to try to modify the patterns of consumption within the family by shedding light on the children sector, 
which is one of the most important sectors co-existing with ads in thought, conscience and social behavior, and trying to direct them to benefit from the ads in a positive way away from the negative aspects.

According to the above, the main objective of this study is to know the role of commercial ads in influencing the purchasing decision of parents through identifying the ability of advertising message content to identify the nature of products and understand it by children from all ages, and the impact of continuous exposure of advertising on the purchasing decision some children products. The study is also concerned of identifying the role of using characters, particularly children characters in the effect over children, and also on parents' purchasing decision, in addition to identifying the most important advertising means of the greatest effect on children in order to create awareness and response among them towards the advertised products, and specifying the most appropriate time for this.

The purpose of this study is to shed very much light on children to identify the extent of commercial advertisements impact on them according to their age and intellectual maturity, and the role of these ads in creating awareness in them and then they become interested in the advertised products until reaching their respond in order to make purchasing decision. The study also aims at identifying the effective role of commercials ads in influencing the decision to buy children's products either directly through the direct exposure of parents to these advertisements or indirectly through the influence of children on them and creating a response in them to make decision to purchase their products.

This study will help us reach a set of conclusions and recommendations that will help advertisers identify parents' attitudes towards advertising targeting children and the extent of impact of commercial ads on the relationship between children effective approaches and parents' response strategies, in addition to creating awareness among parents towards the advertised products direction and how they affect their children.

\section{Study Framework}

Based on the knowledge of researchers of previous studies, the following model has been proposed. The model explains the role of commercial ads among children in influencing the purchasing decision. Many previous studies that dealt with the subject from different angles have been utilized to determine the independent variables that may affect the dependent variable. The following is an explanation of how variables are measured: (see study framework in Fig.1).

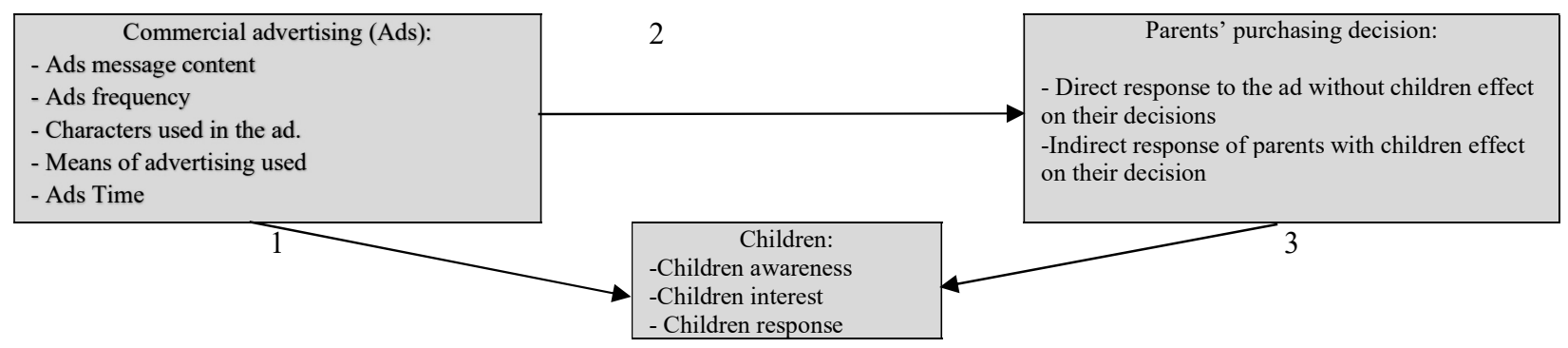

Fig. 1. The structure of the proposed study

\section{Literature Review}

\subsection{Theoretical Background on the Study's Constructs}

There is no doubt that children are influenced by their parents and they influence them at the same time to make a decision to purchase their products. The relationship between them is a reciprocal relationship, where parents work to transfer their experiences and information to their children and train them to make decisions. At the same time, children affect parents as soon as they have communication skills and become exposed to many external influences such as commercials ads that can create a great awareness and interest in products, making them a great source of information and participants in decision making. This is because watching ads and continuous exposure to them through different means clearly affect the children in many aspects, especially the consumption side through various means.

\subsection{Commercials Advertising}

Advertising as one of the modes of promoting goods and services, it is a communication process aiming at influencing the purchasing decision, where the ad works to distribute advertising messages over consumers to encourage them to purchase goods or services (Al-Alaq \& Rabaia, 2010:136). Among the most important factors that help advertising generate positive selling effects is the content of the advertisement, where the qualities of the product and the practical advantages of it should be displayed, all of which to achieve mental attraction, which emphasizes the facts and logical aspects in order to urge the public to purchase products that are very suitable to their needs. These mental ads affect parents because of the information contained in them, contrary to emotional advertisements that affect children as a result of attracting them and focus on addressing their emotions through psychological and social needs such as fun, attraction, appreciation and others. This is because emotion requires much less effort than that required by logic (Marwa Al-Hamasmi, 2014: 37). 
In addition, the repetition of the presentation of the advertisement is an effective tool to fight forgetfulness by continuing to broadcast and display it so that the consumer does not forget it. (Al-Alaq \& Rabaia, 2010:175). The results indicate that the higher the frequency of repetition, the more learning and greater impact; the frequency should be taken into consideration provided that the consumer will not get bored. Advertising wear out is one of the important factors that leads to fixing skills and information the individual has learnt, leading to better distinction of the repeated thing than others. (Ahmed Almasri, 2000: 388). So, the importance of repetition of the advertisement emerges, as it works to install the message in the public minds of and store the information contained in the advertisement in public memory so that they spontaneously emerge in their minds in the right time and circumstances (Al-Alaq \& Rabaia, 2010:160).

The use of characters in ads, especially famous children and cartoon characters, has a great role in attracting the attention of children and creating the intention to purchase (Nicolini et al., 2017). The use of characters in advertising has shown its effectiveness in making the child believe in the qualities of the product and affect his purchasing demands (Saraf, 2013), and that is through television channels, social network and kids websites (Ustjanauskas et al., 2014), taking into consideration the times which children watch the ad., where some believe that there are peak times to watch the ad. (Alalq, 2010:175), or is time no longer important, due to the possibility of viewing them on social networking sites which are available to all and at all time?

Accordingly, commercial ads play a big role in influencing consumers' purchasing behavior, as well as their abilities to control individuals, whether adults or children, by directing them to acquire the products.

\subsection{Children}

Children are considered to be an important pillar of society and a fundamental part of its structure. The influence of the media on them has increased significantly and on their behavior and way of thinking, because to the nature and variables of the family are important for marketing directed towards the end consumer, especially that the family is a consumer system in society and represents the main unit of consumption.

There is a clear impact on the children's purchasing decisions as a result of the children's access and exposure to various means of communication, which gives them the opportunity to know about everything new. The difference in the number of children that is the small number of them in the family increases the care on them, on their views and keenness to respond to their requests. The impact of the age of children varies from age to age (Sweidan, 2011); children aged 7 years might have more positive attitude towards the ads. (Baiocco, et al., 2009). Likewise, children gender differences affect their responses to advertising, therefore there must be differences between male-oriented and female-oriented ads because of their different orientation and reactions (Bakir et al., 2008). Children naturally have a tendency to love buying and imitation, but the presence of ads as a permanent incentive for them makes them more inclined to buy and they use many methods of pressure and influence on their parents to make a purchasing decision (Mustafa et al., 2013). They are often keen to act the ads they are influenced by verbally or in the form of movements in order to express and comfort themselves. The children now have a great ability to learn, preserve and comprehend, especially in light potentialities and the resources they possess to play their role effectively in life (Aldwaik, 2011). This makes children a vital market and an important target for advertisers because of what they possess. However, children are still vulnerable and need to be protected, so that some ads must be banned and controlled.

\subsection{Parent's purchase decision}

The purchasing decision-making process involves recognizing the need and the imbalance status of the consumer, as a result of comparing the current situation with that he desires to reach. One of the most important factors influencing the purchasing decision is the size of the family, which constitutes a process of interaction between children and parents who control the decision-making process. The decision-making process begins early before the decision and ends after evaluation. This requires organizations to pay attention to the nature and stages of purchasing behavior, as well as the roles and patterns of this behavior and the most important factors affecting it. In all cases, the purchasing decision of the consumer stems from his desire to obtain a certain benefit. This desire is influenced by a set of environmental restrictions and the impact of marketing policies on him, in addition to many other influences such as income, economic and social factors. This requires determining the relative weight of all variables surrounding and influencing the consumer's purchasing decision (Al-Alaq \& Rabaia, 2010, 28). There are many reasons that lead marketers to understand how the consumer makes the purchasing decision, the most important of which is the consumer interaction with the marketing strategies of the organization, which has a clear impact on its success, in addition to the contribution of the marketing mix made by the organization to satisfy consumers' needs and desires. The deep understanding of factors affecting consumer decision-making will enable marketers to better predict consumer's responses towards their marketing strategies (Pride \& Ferrell, 2006, 233). Every decision made by the consumer will be a response to a problem that may appear to him and is very diverse in many areas, where purchasing decision-making is based on elements and emotional reactions, rather than a result of a rational process (Solomon, 2015, p: 59-91). The question arising here and should be addressed is how consumers make their purchasing decision? Which is variant. For example, if a certain advertisement for a product that is not used frequently? Or rarely bought by the consumer, the organization in this case should give full details for this product because the consumer does not have specific criteria or previous experiences of this product to build his evaluation of it. In purchasing decision terminology, this is called "Extensive problem solution." 
On the contrary, if the consumer is exposed to an ad of a product that he/she has previous experience and purchases it frequently, the advertiser in this case does not need to talk about the details and characteristics of this advertised product because this consumer has the ability to build criteria to evaluate this product, which will make him able to make the purchasing decision; this termed in purchasing decision "Routinized response behavior" (Schiffman \& Wisenblit, 2015, p: 366).

Hence, it is clear that the purchasing decision of the consumer is based on how the consumer makes the decision within a given model, taking into account the impact of psychological and social factors influencing his decision making process, and the determining of his needs and desires, as well as the degree of his awareness when choosing any products, in addition to determining the most important information he needs about the product and the sources of access to it and how to evaluate the alternatives available. (Schiffman \& Wisenblit, 2015, p: 369). The decision making process is complex and requires a deep understanding of decision makers and marketers in organizations to predict the most important factors influencing this decision to build their marketing strategies that must meet the consumers' needs, especially the advertising policies applied in terms of advertising message content, frequency degree of the ad., characters used in the advertisement, in addition to the means of advertising used and the time of presentation, which may affect the consumers' purchasing decision, and make them respond to the advertisement directly or indirectly .

\section{Study Hypotheses}

\subsection{The role of commercial advertising on children}

The commercials ads affect children more than parents because parents are worried about this effect, which requires them to know what children watch. This does not happen unless parents see the impact of advertising on their children (Tsfati et al., 2005). Opinion polls have confirmed discrepancies between children and parents about the attitudes of both parties towards advertising, and how these ads influence stages of children's growth, behavior and purchasing orientation (Baiocco et al., 2009). When children are targeted, the content of the ad., frequency is on focus, where it was observed that children respond at a large scale to the change in the level of frequency and the time of presenting the ad. (Gorn \& Goldberg, 1980), in addition to focusing on the use of animation especially in programs for children and social media sites. (Maryam Amini et al., 2014). Some of the ads have had a great impact on children, particularly ads on easily accessible goods. The impact differs according to differences between male and female, where ads directed to males should be distinguished from those directed to females due to differences in reactions towards the ads (Bakir et al., 2008). Based on of that, the following hypothesis has been formulated:

$\mathrm{H}_{1}$ : There is no role for commercials advertising in influencing children.

This variable is measured in paragraphs (1-33) of the questionnaire will be in Part II.

\subsection{Commercial ads, purchase decision of parents}

Parents' understanding of the advertisements is more than that of children, and their ability to distinguish between products is higher (Thomas et al., 2014). So, the parents' role in influencing the children's understanding of the ad is different, depending on the gender of parents (father or mother), their level of education, their age and their job (Abdali, 2011), in addition to family size and its income average (Aldwaik, 2011). This is due to the fact that families of low income will reject purchase; which generates feeling of deprivation among children. This requires that the ads should not include misleading and encouraging information for consumption. Moreover, ads give information about the advertised products, where children watch ads without parents' consent to satisfy their desires as parents are busy for long time away from them. So, the following hypothesis is formulated:

$\mathrm{H}_{2}$ : There is no effect of commercials ads on parents' purchasing decision.

These variables in paragraphs (34-49) of the questionnaire will be measured in Part III.

\subsection{Children and the parents' purchasing decision}

Children are seen as a vital market and an important target for advertisers, as children have the ability to understand, collect information and be influenced by them, and this is why they are the focus of many government agencies and researchers in social sciences because of their importance and role in influencing the decision. The child is able to perceive and respond to audio and visual means and capable of thinking about the information presented to him (Gorn et al., 1980).

$\mathrm{H}_{3}$ : There is no role for children in influencing the parents' purchasing decision.

This variable in paragraphs 50-64 of the questionnaire will be measured in Part III.

Fig. 1 summarizes the default relationship between all variables. 


\section{Research Methodology}

The study follows the descriptive-analytical method by addressing the theoretical framework and previous studies, as well as analyzing the data and testing hypotheses through the questionnaire prepared for this purpose.In addition, a questionnaire has been prepared and developed to address many paragraphs related to the independent variable and dependent variables, using the five- Likert scale (strongly agree, agree, neutral, disagree, strongly disagree). The questionnaire is divided into two main parts: the first part deals with personal data of one of the parents, who has filled out the questionnaire and the second part is concerned with determining the role of commercial ads in children in influencing parents' purchasing decision.

\subsection{Study population and study sample}

This study was conducted in Jordan during the summer of 2018 on Jordanian society in Amman region and the largest Jordanian cities like Irbid, and Zarqa. A simple random sample was selected. 530 samples were distributed, 490 of them were retrieved, and 16 were excluded. The study population consisted of the parents of different ages and categories. The number of valid questionnaires was 474 that was $89.43 \%$ of the sample size. The sample consisted of $41.6 \%$ males (fathers), $58.4 \%$ females (mothers), (16.2\%) of them aged $20-30$ years, $41.8 \%$ aged $31-40$ years old, $34 \%$ aged $41-50$, aged $8 \%$ over 51 . The number of children in the family was $1-3$ children, $67.1 \%, 4-7$ children, $29.7 \%, 7$ children and more, $3.2 \%$. $15.2 \%$ of the sample have General Secondary and or less, 7.2\% with Diploma, 60.8\% Bachelor, 16.9\% Postgraduate. 92.4\% of the sample were married, $2.9 \%$ divorced and $5.1 \%$ widowed. The percentage of respondents earning less than 500 JD was $5.3 \%$, from 500 to 1000 JD $50.8 \%$, JD1500, 19.8\%, 1500-2000 JD $16.2 \%$, JD 2000 by $7.8 \%$. The percentage of those working in the public sector is $12.7 \%, 49.6 \%$ in the private sector, $18.8 \%$ self-employed, and $19 \%$ unemployed. The proportion of families with children aged $2-5$ years was $41.1 \%, 5-8,48.1 \%, 8-11,43.9 \%$, and $11-14,28.7 \%, 16.9 \%$ of the sample have male children, $5.5 \%$ haven female children, $77.6 \%$ had females and males.

\subsection{Validity and reliability}

In order to test the validity of study measures, content validity and construct validity were used. Based on extensive literature review and interviews with academic experts in the field, content validity was supported. Construct validity measures whether a scale is an appropriate operational definition of a construct (Flynn et al., 1990). Construct validity was done by A principal component factor analysis with varimax rotation after collecting data (Hair et al., 2013). Table 1 and Table 2 present the results and all items loaded strongly $(0.5)$ on their appropriate factors which supported their unidimensionality (Hair et al., 2013).

Table 1

Independent variable constructs

\begin{tabular}{|c|c|c|c|c|c|}
\hline Content of advertising message & Factor loading & Reliability & Ads Time. & Factor loading & Reliability \\
\hline 1 & 0.524 & \multirow{12}{*}{0.803} & 30 & 0.819 & 0.712 \\
\hline 2 & 0.527 & & 31 & 0.833 & \\
\hline 3 & 0.634 & & 32 & 0.557 & \\
\hline 4 & 0.686 & & 33 & 0.556 & \\
\hline 5 & 0.714 & & Children awareness & Factor loading & Reliability \\
\hline 6 & 0.621 & & 34 & 0.751 & 0.862 \\
\hline 7 & 0.797 & & 35 & 0.61 & \\
\hline 8 & 0.585 & & 36 & 0.658 & \\
\hline 9 & 0.537 & & 37 & 0.678 & \\
\hline 10 & 0.692 & & 38 & 0.465 & \\
\hline 11 & 0.618 & & 39 & 0.597 & \\
\hline 12 & 0.669 & & 40 & 0.751 & \\
\hline Ads frequency & Factor loading & \multirow[t]{2}{*}{ Reliability } & Children interest & Factor loading & Reliability \\
\hline 13 & 0.831 & & 41 & 0.666 & 0.701 \\
\hline 14 & 0.636 & \multirow[t]{2}{*}{0.741} & 42 & 0.528 & \\
\hline 15 & 0.745 & & 43 & 0.763 & \\
\hline Characters used in the ad. & Factor loading & \multirow[t]{3}{*}{ Reliability } & 44 & 0.749 & \\
\hline 16 & 0.673 & & Children response & Factor loading & Reliability \\
\hline 17 & 0.711 & & 45 & 0.875 & 0.776 \\
\hline 18 & 0.721 & \multirow[t]{3}{*}{0.89} & 46 & 0.917 & \\
\hline 19 & 0.735 & & 47 & 0.623 & \\
\hline 20 & 0.505 & & 48 & 0.742 & \\
\hline means of ads & Factor loading & \multirow[t]{5}{*}{ Reliability } & 49 & 0.571 & \\
\hline 21 & 0.663 & & & & \\
\hline 22 & 0.559 & & & & \\
\hline 23 & 0.718 & & & & \\
\hline 24 & 0.792 & & & & \\
\hline 25 & 0.868 & \multirow[t]{5}{*}{0.725} & & & \\
\hline 26 & 0.833 & & & & \\
\hline 27 & 0.567 & & & & \\
\hline 28 & 0.536 & & & & \\
\hline 29 & 0.582 & & & & \\
\hline
\end{tabular}


Table 2

The results of factor analysis for direct and indirect response to advertisement

\begin{tabular}{|c|c|c|c|c|c|}
\hline $\begin{array}{l}\text { Direct response to the ad. without the } \\
\text { children's influence on their decision }\end{array}$ & $\begin{array}{l}\text { Factor } \\
\text { loading }\end{array}$ & Reliability & $\begin{array}{l}\text { indirect response to ad. } \\
\text { through the effect of kids } \\
\text { on their decision }\end{array}$ & $\begin{array}{l}\text { Factor } \\
\text { loading }\end{array}$ & Reliability \\
\hline 50 & .781 & \multirow{9}{*}{.803} & 59 & .582 & \multirow{9}{*}{.827} \\
\hline 51 & .760 & & 60 & .664 & \\
\hline 52 & .631 & & 61 & .698 & \\
\hline 53 & .712 & & 62 & .592 & \\
\hline 54 & .694 & & 63 & .680 & \\
\hline 55 & .704 & & \multirow[t]{4}{*}{64} & \multirow[t]{4}{*}{.714} & \\
\hline 56 & .681 & & & & \\
\hline 57 & .572 & & & & \\
\hline 58 & .610 & & & & \\
\hline
\end{tabular}

Reliability was operationalized using internal consistency method value for attract and stimulate attention in the booth exhibition equal .833 , approaching the sales meeting was equal to .841 , identify the visitors' goals and recognize their needs was equal to .867 , sales presentation was equal to .855 , respond to visitor objection was equal to .765 , closing the sale was equal to .859 and visitors purchasing behavior was equal to .777 . Generally, these values exceed recommended minimum 0.7 (Nuannlly, 1978), and this result establishes the reliability of all the theoretical constructs.

\subsection{The results of some basic statistics}

Table 3 shows the means, standard deviations and inter-correlations of competitive strategies, SCI and performance.

Table 3

Correlations, means and standard deviations

\begin{tabular}{|c|c|c|c|c|c|c|c|c|c|c|c|}
\hline Variable & Mean & Std & 1 & 2 & 3 & 4 & 5 & 1 & 2 & 3 & 1 \\
\hline 1 & 4.03 & .401 & & & & & & & & & \\
\hline 2 & 3.88 & .572 & .061 & & & & & & & & \\
\hline 3 & 3.96 & .574 & $.547^{*}$ & $.291 *$ & & & & & & & \\
\hline 4 & 3.53 & .468 & $.228^{*}$ & $.287 *$ & $.497 *$ & & & & & & \\
\hline 5 & 3.31 & .514 & .020 & $.241 *$ & $.272 *$ & $.444^{*}$ & & & & & \\
\hline 1 & 4.16 & .508 & $.335^{*}$ & $.385^{*}$ & $.408 *$ & $.473^{*}$ & $.236^{*}$ & & & & \\
\hline 2 & 3.31 & .551 & .087 & $.232 *$ & $.371 *$ & $.400^{*}$ & $.343^{*}$ & $.301^{*}$ & & & \\
\hline 3 & 3.80 & .581 & $.310^{*}$ & $.169 *$ & $.301 *$ & $.568^{*}$ & .077 & $.430 *$ & $.219^{*}$ & & \\
\hline 1 & 3.72 & .587 & $.315^{*}$ & $.255^{*}$ & $.298 *$ & $.453^{*}$ & $.158^{*}$ & $.406^{*}$ & $.148 *$ & $.594^{*}$ & \\
\hline 2 & 3.75 & .629 & $.433^{*}$ & $.253 *$ & $.419 *$ & $.461 *$ & $.288^{*}$ & $.477 *$ & $.358 *$ & $.605^{*}$ & $.587 *$ \\
\hline
\end{tabular}

Sig $<.05$

\subsection{Hypothesis testing}

\subsubsection{The first hypothesis: The direct effect of commercial ads on children}

Table 4 presents the results of the effect of commercial advertisement on children purchase intension.

Table 4

The summary of the results of regression analysis for testing the first hypothesis

\begin{tabular}{|c|c|c|c|c|c|c|c|c|c|}
\hline \multirow[t]{2}{*}{ Variables } & \multicolumn{3}{|c|}{ Children awareness } & \multicolumn{3}{|c|}{ Children interest } & \multicolumn{3}{|c|}{ Children's response } \\
\hline & $\beta$ & t-value & Sig & $\beta$ & t-value & Sig & $\beta$ & t-value & Sig \\
\hline ads message content & .252 & $5.687 *$ & .000 & .114 & $2.325^{*}$ & .021 & .218 & $4.979 *$ & .000 \\
\hline Ads Frequency & .295 & $7.538^{*}$ & .000 & .063 & 1.453 & .147 & .048 & 1.245 & .214 \\
\hline Individuals used in the Ads: & .042 & .837 & .403 & .270 & $4.862 *$ & .000 & .097 & 1.944 & .053 \\
\hline Ads medium used & .297 & $6.527 *$ & .000 & .199 & $3.957 *$ & .000 & .640 & $14.270^{*}$ & .000 \\
\hline Advertising Time & .024 & .589 & .556 & .169 & $3.686^{*}$ & .000 & .197 & $4.818^{*}$ & .000 \\
\hline $\mathrm{R}^{2}$ & & .377 & & & .242 & & & .395 & \\
\hline $\mathrm{F}$ & & $56.711 *$ & & & $29.960 *$ & & & $61.211^{*}$ & \\
\hline
\end{tabular}

The results of the regression analysis summarized in Table 4 show that independent variables significantly affect children's awareness $(\mathrm{F}=56.711, P<0.01)$ and $\mathrm{R}^{2}$ stands for coefficient of determination signifies the amount of variation in the dependent variables explained by the regression model. $\mathrm{R}^{2}$ value of 0.377 and above considered as good fit in case of multiple regression. They also show a significant direct effects of ads message content $(\beta=.252, \mathrm{P}<.05)$, ads Frequency $(\beta=.295, \mathrm{P}<.05)$, Ads medium used $(\beta=.297, \mathrm{P}<.05)$ on children's awareness. The results of the regression analysis summarized in Table 4 show that independent variable significantly affect Children's interest $(\mathrm{F}=29.960, P<0.01)$ and. $\mathrm{R}^{2}$ value of 0.242 and above is considered as good fit in case of multiple regression. They also show a significant direct effect of ads message content $(\beta=.114, \mathrm{P}<.05)$, Individuals used in the Ads $(\beta=.270, \mathrm{P}<.05)$, Ads medium used $(\beta=.119, \mathrm{P}<.05)$ and Advertising Time $(\beta=.169, \mathrm{P}<.05)$ on children's interest. Finally, the results of the regression analysis summarized in Table 4 show that inde- 
pendent variable significantly influences on children response $(\mathrm{F}=61.211, P<0.01)$ and. $\mathrm{R}^{2}$ value 0.395 and above is considered as good model fit for the case of multiple regression. They also show a significant direct effect of ads message content $(\beta=218, \mathrm{P}<.05)$, Ads medium used $(\beta=.640, \mathrm{P}<.05)$ and Advertising Time $(\beta=.197, \mathrm{P}<.05)$ on Children response.

\subsubsection{The second hypothesis: The effect of commercial advertisement on parent's purchase decision}

Table 5

The results of multiple regression analysis for testing the second hypothesis

\begin{tabular}{|c|c|c|c|c|c|c|}
\hline \multirow[t]{2}{*}{ Variables } & \multicolumn{3}{|c|}{$\begin{array}{l}\text { Direct response to Ads without effect of chil- } \\
\text { dren on their decision }\end{array}$} & \multicolumn{3}{|c|}{$\begin{array}{l}\text { Indirect response of Ads through the } \\
\text { effect of children on their decision }\end{array}$} \\
\hline & $\mathrm{B}$ & t-value & Sig & $\mathrm{B}$ & t-value & Sig \\
\hline ads message content & .256 & $5.357^{*}$ & .000 & .346 & $7.659^{*}$ & .000 \\
\hline ads Frequency & .155 & $3.675^{*}$ & .000 & .114 & $2.862 *$ & .004 \\
\hline Individuals used in the Ads: & -.079 & -1.443 & .150 & .022 & .430 & .667 \\
\hline Ads medium used & .408 & $8.311^{*}$ & .000 & .285 & $6.150 *$ & .000 \\
\hline Advertising Time & -.044 & -.981 & .327 & .121 & $2.860 *$ & .004 \\
\hline $\mathrm{R}^{2}$ & \multicolumn{3}{|c|}{.275} & \multicolumn{3}{|c|}{.354} \\
\hline $\mathrm{F}$ & \multicolumn{3}{|c|}{35.506} & \multicolumn{3}{|c|}{51.331} \\
\hline
\end{tabular}

We examine how commercial ads affects parent's purchase decision. Models 1 and 2 in Table 5 are both significant at the $\mathrm{p}=0.05$ level $\left(\mathrm{R}^{2}=0.275\right.$ and 0.354$)$ and explain an additional $27.5 \%$ and $35.4 \%$ of variance on parent's purchase decision. Table 5 depicts the impact of commercial ads on direct response to Ads without the effect of children on their decision which appeared through: ads message content $(\beta=.256, \mathrm{P}<.05)$, ads Frequency $(\beta=.155, \mathrm{P}<.05)$ and Ads medium used $(\beta=.408$, $\mathrm{P}<.05$ ). Table 5 depicts the impact of commercial ads on indirect response of ads through the effect of children on their decision which appeared through: ads message content $(\beta=.346, \mathrm{P}<.05)$, ads Frequency $(\beta=.114, \mathrm{P}<.05)$, Ads medium used $(\beta=.285, \mathrm{P}<.05)$ and Advertising Time $(\beta=.121, \mathrm{P}<.05)$

\subsubsection{The third hypothesis: The direct effect of children on parent's purchase decision}

Table 6 presents the results of regression analysis regarding the effects of Children on parent's purchase decision. Models 1 and 2 capture the direct effects of Children on parent's purchase decision. They are both significant at the $p=0.05$ level $\left(R^{2}=\right.$ 0.380 and 0.451 ). Coefficients of children awareness and children response are positive and significant for direct response to Ads without effect of children on their decision $(\beta=.187$ and $\beta=.520)$ respectively. Similarly, Coefficients of children awareness, children interest and children response are positive and significant for indirect response of Ads through the effect of children on their decision $(\beta=.202, \beta=.190$ and $\beta=.477)$, respectively.

Table 6

Multiple regression analysis for testing the third hypothesis

\begin{tabular}{|c|c|c|c|c|c|c|}
\hline \multirow[t]{2}{*}{ Variables } & \multicolumn{3}{|c|}{$\begin{array}{l}\text { Direct response to Ads without effect of } \\
\text { children on their decision }\end{array}$} & \multicolumn{3}{|c|}{$\begin{array}{l}\text { Indirect response of Ads through the effect of children } \\
\text { on their decision }\end{array}$} \\
\hline & $\beta$ & t-value & Sig & $\mathrm{B}$ & t-value & Sig \\
\hline Children awareness, & .187 & $4.503 *$ & .000 & .202 & $5.177 *$ & .000 \\
\hline children interest & .024 & .628 & .530 & .190 & $5.261^{*}$ & .000 \\
\hline Children's response & .520 & $12.889^{*}$ & .000 & .477 & $12.572 *$ & .000 \\
\hline $\mathrm{R}^{2}$ & .380 & & & .451 & & \\
\hline $\mathrm{F}$ & $96.062 *$ & & & $128.536^{*}$ & & \\
\hline
\end{tabular}

\section{Discussion and conclusions}

- Through the first and the second tables, the paragraphs reliability have been analyzed. It is clear that that all paragraphs of independent variables (commercials ads), and the intermediary (children), and the dependent variable (parents' purchasing decision) were good with regard to percentages, all which varied from $70 \%-87.9 \%$, and they were high coefficients. This is an evidence of the consistency of the results. This was confirmed by Factor Analysis, and leads to stable results of the questionnaire, and that they and do not change significantly. This makes us fully confident about the validity of the questionnaire, and its validity for analysis and interpretation of the study results and testing its hypotheses.

- Table 3 (correlation coefficient)

The mean of the independent variables (commercials ads) ranged from $3.31 \%$ to $4.03 \%$, while the intermediary variables (children) ranged between 3.31\% and 4.16\%, whereas the dependent variables (parents' purchasing decision) ranged between $3.72 \%$ and $3.75 \%$. This explains the extent of the relationship between the different phenomena, and it is clear that all the means of all variables are greater than 3 and this indicates a positive direction.

-When testing the first hypothesis (there is no role for commercials ads in influencing the children), it emerges that the independent variables of (advertisement messages, frequency of ads, and means of advertising used) have an effect on the intermediary variable (children awareness). (The characters used in the ad., the means of advertisement used, time of the ad.) 
Finally, the independent variables regarding (ad. Messages, means used, time of the ad.) have effect over the dependent variable of children response.

In general, however, according to the value of $\mathrm{F}$, the overall independent variables (commercial ads) have effect on intermediary variables (children), which is a statistically significant. Thus, the null hypothesis is rejected, and the alternative one is accepted. This means that there is an effect for independent variables (commercial ads) over intermediary ones (children).

-When testing the second hypothesis, (there was no effect of commercial ads on the (parents' purchasing decision) it emerged that the independent variables of (ad message, frequency of advertising, and the means of advertising used) have impact on the dependent variable (parents' direct response to the ad. without children's influence on their decision), while the independent variables (ad messages, ad frequency, means of advertising used, and time of ad.) have impact on the dependent variable (indirect parents' response to ad. through children's influence on their decision).

However, according to the value of F, all independent variables (commercial ad.) have an effect on the dependent variable (parents' purchasing decision), which is a statistically significant. Thus, the null hypothesis shall be rejected and the alternative hypothesis will be accepted. This means that independent variables (commercial ads) have effect on the dependent variable (parents' purchasing decision).

- When testing the third hypothesis (there is no role for children in influencing the parents' purchasing decision), it emerges that the intermediary variables (children awareness and response) have an impact on the dependent variable (parents' direct response to ad. without children influencing on their decision), while all intermediary variables (awareness, interest, and response of children) have impact on the dependent variable (indirect response of parents to the ad. through children's influence on their decision). According to the value of F, the overall intermediary variables (children) have effect on the dependent variable (parents' purchasing decision), which is statistically significance. Thus, the null hypothesis shall be rejected and the alternative hypothesis will be accepted. This means that the intermediary variables have effect (children) on the dependent variables (parents' purchasing decision).

Through the above, the direct effect of the independent variable (commercial ads) on the dependent variable (parents' purchasing decision) without the existence of the intermediary variable (children), which signifies that the inclusion of the intermediary variable into the model has direct and indirect impact, but its impact is relative rather than total. There is therefore an effect for the independent variables (commercial ads) on the dependent variable (parents' purchasing decision) with or without the intermediary variable.

\section{Recommendations: Managerial implications}

Based on the previous studies and findings, researchers propose a set of recommendations for decision-makers in to focus on commercial ads whether directed at parents or children to make a direct decision, either directly or indirectly:

-The focus of business organizations on the preparation of advertising messages targeting children because of their impact on their awareness and they raise their interest and create a response to that ad., and to make sure to repeat this message and use various means of advertising, traditional and modern, especially those related to social media over the web.

- The interest of organizations in the content of advertising messages and taking into account the recurrence of the ads at different periods, using multiple advertising means directed to parents, especially when the organization post healthy and useful products for children from the perspective of their parents, where the response will be directly by them.

- The focusing of the organizations in their commercials ads on what the children are interested in, and can create awareness and attention towards these ads, because these things have impact on the purchasing decision of parents and their response to their children requests and needs.

- Take into consideration that there are advertisements directed for parents and others for children because they have impact on the purchasing decision and response to these ads since children can control their parents and make them respond to the purchasing decision.

- Organizations that offer special products for children should design a clear, honest and convincing advertising message, so that parents would not lose confidence in the products of the company and their interest in them. The message should not be traditional, but unique and has disciplined creativity to reflect the goals of the organization and to meet their needs and desires of children and parents alike, and thus changing their attitudes towards these products and adopting them.

- The organizations should repeat the advertisements, taking into account the times and means that suit the target market of the children to ensure appropriate reach rate, frequency and impact.

- The selection of means of advertising is very important, so that we can achieve the highest degree of coverage and penetration, and reach the children at a large scale. The study showed that the means of social media has been one of the best means to deliver this message to children or even parents. 
- Organizations should be interested in post advertising in terms of the way products are displayed and their location in retail stores, so that the child can link between the products displayed in the ads and what he sees in the store in order to create awareness and attention in them, and thus becomes a tool of pressure and response on parents. This is evident in the study results, where parents respond to advertisements through their children and adopt the advertised product.

- Organizations can reduce the budget of the advertising campaign for one of its products by reducing the use of characters or famous characters in the ads because of their low impact on children.

- In their advertisements, organizations should not neglect to create awareness among children and parents until they build loyalty, and thus benefit from the principle of generalization, where they can recall the brand of one of their products in retail stores that appeared in the advertisement, which makes the organization takes advantage of brand consolidation in their minds and disseminates it to the rest of the organization's products.

- Parents play an important role in perceptual defense and thus prevent children-oriented ads from entering their homes. This makes the organizations interested in offering ads that get parents' confidence and interest, and finding advertising means to convey their messages to children at any time.

- The organization should take into account the characteristics and the family life cycle in which the children live and the culture they belong to, in addition to their lifestyle, which creates social upbringing, and thus leads to socialization normalization, and then customer socialization normalization occurs, which directly and indirectly affects the advertising message adopted by the organization.

- Although the study shows the importance of the repetition of the ad for its significance in influencing the purchasing decision, but the repetition of this for a long time without renewing the message may lead to advertising wear out, which leads to adaptation of people and disregarding it very much; in order that this does not happen, the advertising message should be renewed from time to time.

\section{Challenges: Limitation and directions for future research}

One of the main obstacles faced by researchers is the difficulty to fill out the questionnaires by individuals due to lack of time or because of their presence in shopping malls with their families, which necessitated the use of many friends and the need for more time and effort to get as many questionnaires as possible. The little time available did not allow researchers to distribute the questionnaire in different cities of the Kingdom. It was difficult to coordinate between working times and going to places where one of the parents is available. So, the researchers were obliged to do this work during holidays and vacations, in addition to the limited resources that were not enough to enable researchers to distribute a bigger number of questionnaires. However, despite all these difficulties, researchers did not hesitate to distribute the required quantity of questionnaires on the study sample and in several areas, which led us to reach the results described above.

\section{References}

Almasri, A.M. (2000). Advertising. Musasat Shabab Aljamia, Alexandria, Egypt.

Alabdali, S.A. (2011). Studying satellite stations for children and their effect on the pre-school child. Majalal Buhouth Altarbya Alnawiya, 25, $330-386$.

Al-Alaq, B., \& Rabaia, A. (2010). Promotion and commercial advertisement. dar alyazouri alilmya for publication and distribution.

Aldwaik, A. M. (2011). Directions of parents towards T.V ads directed to children and its relationship with patterns of their social and consumption behavior of the family. The sixth Arab annual conference, the third international conference (development of higher education programs in Egypt and the Arab world in light of requirements of the age of knowledge)

Amini, M., Omidvar, N., Yeatman, H., Shariat-Jafari, S., Eslami-Amirabadi, M., \& Zahedirad, M. (2014). Content analysis of food advertising in Iranian children's television programs. International Journal of Preventive Medicine, 5(10), 1337.

Baiocco, R., D'Alessio, M., \& Laghi, F. (2009). Discrepancies between parents' and children's attitudes toward TV advertising. The Journal of Genetic Psychology, 170(2), 176-192.

Bakir, A. (2009). "Some Assembly Required": Comparing Disclaimers in Children's TV Advertising in Turkey and the United States. Journal of Advertising Research, 49(1), 93-103.

Bakir, A., Blodgett, J. G., \& Rose, G. M. (2008). Children's responses to gender-role stereotyped advertisements. Journal of Advertising Research, 48(2), 255-266.

Beales III, J. H., \& Kulick, R. (2013). Does advertising on television cause childhood obesity? A longitudinal analysis. Journal of Public Policy \& Marketing, 32(2), 185-194.

Li, D., Wang, T., Cheng, Y., Zhang, M., Yang, X., Zhu, Z., ... \& Zeng, L. (2016). The extent and nature of television food advertising to children in Xi' an, China. BMC public health, 16(1), 770.

Flynn, B. B., Sakakibara, S., Schroeder, R. G., Bates, K. A., \& Flynn, E. J. (1990). Empirical research methods in operations management. Journal of Operations Management, 9(2), 250-284.

Gorn, G. J., \& Goldberg, M. E. (1980). Children's responses to repetitive television commercials. Journal of Consumer Research, 6(4), 421-424. 
Hair, J. F., Black, W. C., Babin, B. J., \& Anderson, R. E. (2013). Multivariate data analysis: Pearson new international edition. Pearson Higher Ed.

Ip, J., Mehta, K. P., \& Coveney, J. (2007). Exploring parents' perceptions of television food advertising directed at children: A South Australian study. Nutrition \& Dietetics, 64(1), 50-58.

Al-Hamamsi, M.M. (2014). Using comedy in T.V ads and its impact on the child. Almaktab alarabi llmaarif, Cairo, Egypt.

Mustafa, A.M.A., Rajab, J., Rizq, A.N. (2013). A proposed model for the impact of children satellite channels on the relationship between children styles to effect and response of parents. Almajaleh Alilmiya Leltijara wa Aliqtisad, Egypt, 176-226.

Ng, S. H., Kelly, B., Se, C. H., Chinna, K., Sameeha, M. J., Krishnasamy, S., \& Karupaiah, T. (2014). Obesogenic television food advertising to children in Malaysia: sociocultural variations. Global health action, 7(1), 25169.

Nicolini, V., Cassia, F., \& Bellotto, M. (2017). Children perceptions of emotional and rational appeals in social advertisements. Young Consumers, 18(3), 261-277.

Nuannlly, J.C. (1978). Psychometric Theory. New York MC Graw Hill.

Pride, W., \& Ferrell, O. C. (2004). Marketing. Cengage Learning.

Rajab, J. A. (2015). The role of advertisement as one of social upgrowing through the learning of the child the consumption behavior. almajala alilmia leliqtisad and altijara, 1, 285-312.

Saraf, V. (2013). Impact of Celebrity Endorsement on Children through TV Advertisements. International Journal of Marketing \& Business Communication, 2(2).

Schiffman, L.G., \& Wisenblit, J.L. (2015). Consumer Behavior. $11^{\text {th }}$ ed., Pearson Education Limited.

Sener, A., Guven, S., \& Boylu, A. A. (2010). Children and advertising: what do they think about advertisements, how are they affected by advertisements?. Nova Novinka.

Spielvogel, J., \& Terlutter, R. (2013). Development of TV advertising literacy in children: Do physical appearance and eating habits matter?. International Journal of Advertising, 32(3), 343-368.

Sweidan, N.M. (2011). The role of children on some variables of Jordanian family purchasing decisions. Alazhar University Journal, 13, 867-894.

Thomas, S. L., Olds, T., Pettigrew, S., Yeatman, H., Hyde, J., \& Dragovic, C. (2014). Parent and child interactions with two contrasting anti-obesity advertising campaigns: a qualitative analysis. BMC Public Health, 14(1), 151.

Tsfati, Y., Ribak, R., \& Cohen, J. (2005). Rebelde way in Israel: Parental perceptions of television influence and monitoring of children's social and media activities. Mass Communication \& Society, 8(1), 3-22.

Ustjanauskas, A. E., Harris, J. L., \& Schwartz, M. B. (2014). Food and beverage advertising on children's web sites. Pediatric obesity, 9(5), 362-372.

Zalma, A. R., Safiah, M. Y., Ajau, D., \& Khairil Anuar, M. I. (2013). Reliability and validity of television food advertising questionnaire in Malaysia. Health Promotion International, 30(3), 523-530.

\section{Appendix}

Part 1 Ladies and gentlemen

We hope that you agree to participate in this study, which is about the "The Role of Commercial Advertisements Directed to Children in Influencing Parents' Purchasing Decision". Thank you for your cooperation, in filling out this questionnaire.

The information collected will be used for scientific research purposes only.

With all respect.

Yours sincerely,

The researchers

$$
\begin{aligned}
& \text { 1- Sex: () Male (Father) () Female (Mother) } \\
& \text { 2- - Age of parents: ( ) (20-30) ( ) (31-40) ( ) (41-50) } \\
& \text { ( ) } 51 \text { - and more } \\
& \text { 3- Number of kids in the family: ( ) 1-3 4-7 } \\
& \text { ( ) 7-and more }
\end{aligned}
$$

4- Level of education: ( ) secondary school and below ( ) diploma

$$
\text { ( ) BA ( ) Post graduate }
$$

5- Marital status: ( ) married ( ) divorced ( ) Widowed

6- Income : ( ) less than 500 JD （） 500-1000 JD ～～1000-1500

$$
\text { ( ) 1500-2000 JD ( ) over 2000JD }
$$

7- Parents' jobs: ( ) public sector ( ) private sector ( ) self-employed

( ) unemployed

8- Kids' age ( ) (2-5) ( ) $5-8 \quad$ ( ) $11-14$

9- Kids' sex: ( ) male ( ) female

( ) males and females 


\section{Part 2}

To what extent do you agree with the following statements; put " $\mathrm{X}$ " in the appropriate place only, for questions related to "The role of commercials regarding kids' influence on parents' purchasing decision"

\begin{tabular}{|c|c|c|c|c|c|c|}
\hline Order & statement & strongly agree & agree & neutral & $\begin{array}{l}\text { strongly } \\
\text { disagree }\end{array}$ & disagree \\
\hline & Independent variable: commercials & & & & & \\
\hline & 1- Content of advertising message: & & & & & \\
\hline 1 & $\begin{array}{l}\text { The advertiser uses easy language suitable for the ages of the } \\
\text { targeted kids in the ad. }\end{array}$ & & & & & \\
\hline 2 & $\begin{array}{l}\text { Ads. Make my kids know the quality of the products accu- } \\
\text { rately. }\end{array}$ & & & & & \\
\hline 3 & $\begin{array}{l}\text { Ads. couldn't educate my kids about the potential damage of } \\
\text { the products. }\end{array}$ & & & & & \\
\hline 4 & $\begin{array}{l}\text { The use of pictures and drawings helps my kids remember the } \\
\text { ad. and explain its components. }\end{array}$ & & & & & \\
\hline 5 & $\begin{array}{l}\text { The use of pictures and drawings has clear effect on the } \\
\text { child's attitudes towards the advertised item. }\end{array}$ & & & & & \\
\hline 6 & Ads can educate my kids about product components. & & & & & \\
\hline 7 & $\begin{array}{l}\text { The use of singing and music in advertisements may change } \\
\text { the attitudes of my kids. }\end{array}$ & & & & & \\
\hline 8 & $\begin{array}{l}\text { The use of singing and music in ads. enables my kids to ex- } \\
\text { plain the ad. and repeat its components before or after the ex- } \\
\text { posure. }\end{array}$ & & & & & \\
\hline 9 & $\begin{array}{l}\text { The simplicity of the advertisement content helps my kids to } \\
\text { understand and repeat it with the rest of the family even after } \\
\text { stop of the ad. }\end{array}$ & & & & & \\
\hline 10 & $\begin{array}{l}\text { The use of different dialects in ads. for kids does not help } \\
\text { them understand the advertised item. }\end{array}$ & & & & & \\
\hline 11 & $\begin{array}{l}\text { Presenting the ad. in acting manner clearly affects the kids' } \\
\text { choices. }\end{array}$ & & & & & \\
\hline \multirow[t]{2}{*}{12} & $\begin{array}{l}\text { Using animation in ads. makes them more interesting for my } \\
\text { kids. }\end{array}$ & & & & & \\
\hline & 2-Repetition of ad.: & & & & & \\
\hline 13 & $\begin{array}{l}\text { Kids who are most exposed to ads. tend to remember adver- } \\
\text { tising emblems more than other kids. }\end{array}$ & & & & & \\
\hline order & statement & strongly agree & agree & neutral & $\begin{array}{l}\text { strongly } \\
\text { disagree }\end{array}$ & disagree \\
\hline 14 & $\begin{array}{l}\text { The kids' desire to buy the item stops after the ad. has } \\
\text { stopped. }\end{array}$ & & & & & \\
\hline & & & & & & \\
\hline \multirow[t]{2}{*}{15} & $\begin{array}{l}\text { The repletion of ad. continuously for kids makes them able to } \\
\text { distinguish the item and its brand name when they are in sales } \\
\text { points. }\end{array}$ & & & & & \\
\hline & 3-Characters used in ad.: & & & & & \\
\hline 16 & $\begin{array}{l}\text { Advertisers tend to use children in their ads. due to their emo- } \\
\text { tional effect on parents. }\end{array}$ & & & & & \\
\hline 17 & $\begin{array}{l}\text { Advertisers use kids in their ads. because they can imitate } \\
\text { other children of the same age. }\end{array}$ & & & & & \\
\hline 18 & $\begin{array}{l}\text { The use of famous characters from children in ads. contrib- } \\
\text { utes to changing the attitudes of children viewers to those ads. }\end{array}$ & & & & & \\
\hline 19 & $\begin{array}{l}\text { The use of cartoon characters in ads. increases the desire of } \\
\text { my children to get the item advertised. }\end{array}$ & & & & & \\
\hline \multirow[t]{2}{*}{20} & $\begin{array}{l}\text { I think that the use of parents in ads. shall have a great effect } \\
\text { on my kids' choice of the advertised product. }\end{array}$ & & & & & \\
\hline & 4-advertising means uses: & & & & & \\
\hline 21 & $\begin{array}{l}\text { The use of TV in ads, is one of the most effective advertising } \\
\text { means on my kids. }\end{array}$ & & & & & \\
\hline 22 & $\begin{array}{l}\text { TV is no longer effective on kids in light of great communica- } \\
\text { tion development. }\end{array}$ & & & & & \\
\hline 23 & $\begin{array}{l}\text { I think that ads, in children specialized magazines have big } \\
\text { impact on them. }\end{array}$ & & & & & \\
\hline 24 & $\begin{array}{l}\text { Advertisements in magazines affect children over } 10 \text { years } \\
\text { only as they contain material that needs reading and mental } \\
\text { concentration. }\end{array}$ & & & & & \\
\hline 25 & $\begin{array}{l}\text { It is easy for my children to access social media sites and } \\
\text { watch ads. through them. }\end{array}$ & & & & & \\
\hline 26 & $\begin{array}{l}\text { I think that my children are greatly influenced by the ads. al- } \\
\text { located to them through social networks. }\end{array}$ & & & & & \\
\hline order & statement & strongly agree & agree & neutral & $\begin{array}{l}\text { strongly dis- } \\
\text { agree }\end{array}$ & disagree \\
\hline 27 & $\begin{array}{l}\text { My children who are over the age of } 10, \text { are the only ones } \\
\text { able to interact with Facebook ads. }\end{array}$ & & & & & \\
\hline 28 & $\begin{array}{l}\text { I think YouTube is the most widely used by my children and } \\
\text { of different ages. }\end{array}$ & & & & & \\
\hline \multirow[t]{2}{*}{29} & $\begin{array}{l}\text { My kids can interact easily with the ads on the Instagram \& } \\
\text { snapchat. }\end{array}$ & & & & & \\
\hline & 5-Ad. Time: & & & & & \\
\hline 30 & Kids' products are advertised during school holidays. & & & & & \\
\hline 31 & Advertisers choose afternoon times to advertise kid's products. & & & & & \\
\hline 32 & Morning time is the best for advertising kids products & & & & & \\
\hline \multirow[t]{2}{*}{33} & $\begin{array}{l}\text { Time is no longer important for kid's products ads. because } \\
\text { they can see them at any time on social media platforms. }\end{array}$ & & & & & \\
\hline & Intermediate variable: Kids: & & & & & \\
\hline
\end{tabular}




\begin{tabular}{|c|c|c|c|c|c|c|}
\hline & 1-Kids' awareness: & & & & & \\
\hline 34 & $\begin{array}{l}\text { presenting ads in an attractive way attract the attention of my } \\
\text { kids }\end{array}$ & & & & & \\
\hline 35 & Kids' awareness of ads increases as they grow older. & & & & & \\
\hline 36 & $\begin{array}{l}\text { Ads. can create awareness in my kids regarding commodities } \\
\text { brand names. }\end{array}$ & & & & & \\
\hline 37 & Kids pay attention to ads that show their products. & & & & & \\
\hline 38 & $\begin{array}{l}\text { Kids' exposure to commercials creates in them the desire to } \\
\text { buy the advertised commodities. }\end{array}$ & & & & & \\
\hline 39 & $\begin{array}{l}\text { Children imitate the older people when choosing their prod- } \\
\text { ucts. }\end{array}$ & & & & & \\
\hline \multirow[t]{2}{*}{40} & $\begin{array}{l}\text { Commercial aimed at older children can affect young children } \\
\text { because they want to imitate the older ones. }\end{array}$ & & & & & \\
\hline & 2-Interest among kids: & & & & & \\
\hline 41 & kids can't understand the content of ads directed to them & & & & & \\
\hline 42 & $\begin{array}{l}\text { Children can repeat and explain the content of the ad. Even } \\
\text { after a break for a period of time. }\end{array}$ & & & & & \\
\hline order & statement & strongly agree & agree & neutral & $\begin{array}{l}\text { strongly } \\
\text { disagree }\end{array}$ & disagree \\
\hline 43 & $\begin{array}{l}\text { Children over the age of six can evaluate the content of the } \\
\text { ad. and identify the benefits and damages of the advertised } \\
\text { commodities. }\end{array}$ & & & & & \\
\hline \multirow[t]{2}{*}{44} & $\begin{array}{l}\text { Commercials play a key role in changing the attitudes of my } \\
\text { children from the competitive commodity to the advertised } \\
\text { item. }\end{array}$ & & & & & \\
\hline & 3-Kids' response: & & & & & \\
\hline 45 & $\begin{array}{l}\text { Children always insist on parents to buy the item they see in } \\
\text { the ad. }\end{array}$ & & & & & \\
\hline 46 & $\begin{array}{l}\text { Children impose great pressure on parents to buy the item af- } \\
\text { ter watching the ad... }\end{array}$ & & & & & \\
\hline 47 & $\begin{array}{l}\text { Children over } 10 \text { can purchase the advertised item without re- } \\
\text { ferring to their parents. }\end{array}$ & & & & & \\
\hline 48 & $\begin{array}{l}\text { Advertising through social media sites creates a quick re- } \\
\text { sponse in my kids. }\end{array}$ & & & & & \\
\hline \multirow[t]{3}{*}{49} & $\begin{array}{l}\text { Advertising on TV helps to create a quick response in my } \\
\text { kids towards the advertised item more than other kids. }\end{array}$ & & & & & \\
\hline & Dependent variable :parents' purchasing decision: & & & & & \\
\hline & $\begin{array}{l}\text { 1-Direct response to ad. without the effect of their kids on } \\
\text { their decision. }\end{array}$ & & & & & \\
\hline 50 & $\begin{array}{l}\text { The content of the ad. affects the parents' decision to buy } \\
\text { their kids' products }\end{array}$ & & & & & \\
\hline 51 & $\begin{array}{l}\text { Repetition of the ad. Creates the desire amongst parents to } \\
\text { make the decision to buy their kids' products. }\end{array}$ & & & & & \\
\hline 52 & $\begin{array}{l}\text { Characters used in the ad. Can convince parents to make a de- } \\
\text { cision to buy their children's products. }\end{array}$ & & & & & \\
\hline 53 & $\begin{array}{l}\text { Advertising through television makes it easy for parents to } \\
\text { make the decision to buy their kids' products. }\end{array}$ & & & & & \\
\hline 54 & $\begin{array}{l}\text { The advertising of children's products during the evening time } \\
\text { makes parents know more about their children's products and } \\
\text { decide to buy them. }\end{array}$ & & & & & \\
\hline order & statement & strongly agree & agree & neutral & $\begin{array}{l}\text { strongly } \\
\text { disagree }\end{array}$ & disagree \\
\hline 55 & $\begin{array}{l}\text { The emotional feeling of parents towards their kids leads to } \\
\text { their response by making the decision to buy their children's } \\
\text { products. }\end{array}$ & & & & & \\
\hline 56 & $\begin{array}{l}\text { The emotional relationship between parents and children af- } \\
\text { fects parents' decision to buy their children's products. }\end{array}$ & & & & & \\
\hline 57 & $\begin{array}{l}\text { Parents' rejection to respond to their kids' requests leads to } \\
\text { conflict between them. }\end{array}$ & & & & & \\
\hline \multirow[t]{2}{*}{58} & $\begin{array}{l}\text { Parents' limited budget leads them to postpone or reject some } \\
\text { kids' requests. }\end{array}$ & & & & & \\
\hline & $\begin{array}{l}\text { 2-indirect response to ad. Through the effect of kids on } \\
\text { their decision. }\end{array}$ & & & & & \\
\hline 59 & $\begin{array}{l}\text { The repetition of the ad. Creates intellectual awareness in my } \\
\text { kids that makes them able to make the decision to buy their } \\
\text { products. }\end{array}$ & & & & & \\
\hline 60 & $\begin{array}{l}\text { My children's use of social media means educate them to } \\
\text { know more about the features of the product, which makes } \\
\text { them able to persuade parents to make the purchasing deci- } \\
\text { sion. }\end{array}$ & & & & & \\
\hline 61 & $\begin{array}{l}\text { Advertising my children's products during holidays and on } \\
\text { weekends affects my children and makes them able to con- } \\
\text { vince parents to respond to their requests. }\end{array}$ & & & & & \\
\hline 62 & $\begin{array}{l}\text { Parents being busy and away from their kids for a long period } \\
\text { of time, makes them respond to their kids' requests and make } \\
\text { the decision to buy their own products. }\end{array}$ & & & & & \\
\hline 63 & $\begin{array}{l}\text { The small size of the family makes parents respond to their } \\
\text { children's requests and desires to buy the advertised products. }\end{array}$ & & & & & \\
\hline 64 & $\begin{array}{l}\text { Ads. Create a great incentive amongst children to influence } \\
\text { parents to make a decision to buy their own products. }\end{array}$ & & & & & \\
\hline
\end{tabular}


(C) 2020 by the authors; licensee Growing Science, Canada. This is an open access article distributed under the terms and conditions of the Creative Commons Attribution (CCBY) license (http://creativecommons.org/licenses/by/4.0/). 